Evaluating Health and Social Care 


\section{Evaluating Health and Social Care}

Ceri Phillips

Colin Palfrey

and

Paul Thomas 
(C) C. J. Phillips, C. F. Palfrey and P. Thomas 1994

All rights reserved. No reproduction, copy or transmission of this publication may be made without written permission.

No paragraph of this publication may be reproduced, copied or transmitted save with written permission or in accordance with the provisions of the Copyright, Designs and Patents Act 1988, or under the terms of any licence permitting limited copying issued by the Copyright Licensing Agency, 90 Tottenham Court Road, London WIP 9HE.

Any person who does any unauthorised act in relation to this publication may be liable to criminal prosecution and civil claims for damages.

First published 1994 by

THE MACMILLAN PRESS LTD

Houndmills, Basingstoke, Hampshire RG21 2XS

and London

Companies and representatives

throughout the world

ISBN 978-0-333-59186-4

ISBN 978-1-349-23132-4 (eBook)

DOI 10.1007/978-1-349-23132-4

A catalogue record for this book is available from the British Library.

Copy-edited and typeset by Povey-Edmondson

Okehampton and Rochdale, England 


\section{Contents}

List of Figures and Tables vii

Preface $\quad$ ix

1 What is Evaluation? 1

2 Evaluation Research Designs and Methods 27

3 Evaluating Effectiveness 69

4 Evaluating Efficiency $\quad 82$

5 Evaluating Organisational Structures and 103

6 Consumers' Opinions and Service Evaluation 129

7 Evaluating Equality, Equity and Accessibility 155

8 Summing Up 175

$\begin{array}{ll}\text { Index } & 177\end{array}$ 


\section{List of Figures and Tables}

\section{Figures}

2.1 Age profile of employees, bar chart presentation 52

2.2 Age profile of employees, pie chart presentation 53

2.3 The normal distribution 59

2.4 Distribution of data: (a) normal, (b) skewed to the left, (c) skewed to the right

7.1 Wants, needs and supply of services 160

\section{Tables}

2.1 Hypothetical profile of NHS personnel 52

2.2 Age profiles using cumulative frequencies and cumulative percentages

2.3 Data on length of hospital stay 55

4.1 Present value of benefits 91

5.1 Job Diagnostic Survey norms 113 


\section{Preface}

The origins of this book may be traced to the submission of a tender for a research contract to evaluate two major innovative programmes in the field of health and social care. Each of the authors had been interested in the notion of evaluation in the field of health and social care from the perspective of his respective discipline. There was thus a common factor - the field of health and social care - but also many conflicting and opposing views, grounded in the wide variety of approaches and frameworks available to potential evaluators.

We came to the conclusion that there is no one best approach to adopt; each has its merits and limitations. Our own preference is for a framework which combines a number of approaches in such a way that the methods chosen for evaluation are appropriate to the situation and context of the policy being examined. This approach, we argue, removes some of the biases of the discipline based approach and provides a rich and realistic picture in which both successes and failures can be identified. It is not, however, a panacea for problems of evaluation and it is certainly not neutral in any absolute sense. However, we believe that it is likely to be the most useful approach for evaluating policies and programmes in the field of health and social care.

Agencies within health and social care are under increasing pressure to evaluate and improve their performance, for example to measure effectiveness and efficiency and to assess the degree of satisfaction amongst the consumers of their services. The book aims to provide a practical guide for managers, professionals and students who wish to evaluate the performance of social care and health agencies.

Chapter 1 endeavours to answer the question 'What is Evaluation?', whilst at the same time demonstrating the 


\section{x Preface}

limitations of less comprehensive approaches to monitoring and evaluation and emphasising the need to involve the users of services at all stages of the evaluation process.

Chapter 2 deals with evaluation designs and methods, reviewing a range of designs that may be used in constructing an evaluation and considering the types of data that may need to be collected and how they can be collected. It also describes how the data can be checked for its validity and reliability and offers an introduction to the ways in which data can be analysed so as to generate appropriate findings for an evaluation.

Chapters 3-7 explore the main criteria available for evaluating health and social care: effectiveness, efficiency, organisational structures and processes, equality, equity, accessibility and how consumer opinions can be used in the evaluation process. Each chapter explains why these criteria are used, identifies the problems inherent in using them and offers specific guidance on how to use each of the criteria.

Ceri Phillips

Colin Palfrey

Paul Thomas 